\title{
PENGARUH MIND MAPPING DAN GAYA BELAJAR TERHADAP PEMAHAMAN KONSEP SISWA PADA PEMBELAJARAN IPA
}

\author{
Maria Magdalena Emy Rahmawati, C. Asri Budiningsih \\ Program Studi Teknologi Pembelajaran, Universitas Negeri Yogyakarta \\ magdalenaemy@gmail.com
}

\begin{abstract}
Abstrak
Penelitian ini bertujuan untuk mengetahui: (1) perbedaan pemahaman konsep antara siswa yang melaksanakan pembelajaran dengan metode mind mapping dengan siswa yang menggunakan metode ceramah dan presentasi, (2) perbedaan pemahaman konsep siswa yang memiliki gaya belajar berbeda (visual, auditori, dan kinestetik), (3) pengaruh antara metode pembelajaran mind mapping dengan gaya belajar terhadap pemahaman konsep siswa. Penelitian ini merupakan penelitian kuasi eksperimen, dengan desain faktorial $2 \times 3$. Populasi dalam penelitian ini adalah siswa kelas VII SMP Santa Maria Fatima pada semester genap tahun ajaran 2012/2013. Hasil penelitian menunjukkan sebagai berikut. (1) Terdapat perbedaan pemahaman konsep antara siswa yang melaksanakan pembelajaran dengan metode mind mapping dengan siswa yang menggunakan metode ceramah dan presentasi. (2) Tidak terdapat perbedaan pemahaman konsep antara siswa dengan gaya belajar visual, auditori, dan kinestetik. (3) Tidak terdapat pengaruh antara metode pembelajaran mind mapping dengan gaya belajar terhadap pemahaman konsep siswa.
\end{abstract}

Kata kunci: mind mapping, gaya belajar, pemahaman konsep siswa

\section{THE EFFECTS OF MIND MAPPING AND THE LEARNING'S STYLE ON STUDENT'S CONCEPT UNDERSTANDING IN NATURAL SCIENCE LEARNING}

\author{
Maria Magdalena Emy Rahmawati, C. Asri Budiningsih \\ Program Studi Teknologi Pembelajaran, Universitas Negeri Yogyakarta \\ magdalenaemy@gmail.com
}

\begin{abstract}
This research aims to find out: (1) the difference of concept understanding between students who use mind mapping method and students who use lecture method and presentation, (2) the difference in the concept understanding among students with different learning's style (visual, auditory, and kinesthetic), (3) the effect of mind mapping method and student's learning style on concept understanding. The research was a quasi-experimental study using factorial $2 x 3$ designs. The population comprised grade VII student of SMP Santa Maria Fatima in the second semester of the academic year of 2012/2013. The results are as follows. (1) There is a difference in concept understanding between students who use mind mapping method and students who use lecture method and presentation. (2) There is no significant difference in the students' concept understanding among the students with different learning style (visual, auditory, and kinesthetic). (3) There is no effect of mind mapping method and students' learning style on concept understanding.
\end{abstract}

Keywords: mind mapping, learning style, students' concept understanding 


\section{Pendahuluan}

Belajar menurut teori kognitif adalah perubahan persepsi dan pemahaman, yang tidak selalu berbentuk tingkah laku yang dapat diamati dan diukur. Teori tersebut berasumsi bahwa setiap orang telah memiliki pengetahuan dan pengalaman yang telah tertata dalam bentuk struktur kognitif yang dimilikinya (Budiningsih, 2005, p.51). Dalam teori belajar kognitif, Bruner berpendapat bahwa belajar didasarkan pada dua asumsi. Asumsi pertama ialah perolehan pengetahuan merupakan suatu proses interaktif, siswa belajar berinteraksi dengan lingkungannya secara aktif, perubahan tidak hanya terjadi di lingkungan tetapi juga dalam siswa itu sendiri. Asumsi kedua adalah siswa mengkonstruksi pengetahuannya dengan menghubungkan informasi yang masuk dengan informasi yang disimpan yang diperoleh sebelumnya.

Dalam proses pembelajaran IPA, Weiss (Martin, et. al, 2005, p.5) menyatakan bahwa guru dapat menggunakan berbagai metode pembelajaran yang dapat mengembangkan pengetahuan, pemahaman, keterampilan, dan nilai-nilai moral yang berkaitan dengan perkembangan ilmu pengetahuan dan teknologi dewasa ini. Untuk itu perlu dipilih metode pembelajaran yang sesuai dengan materi pembelajaran dan kondisi fisik maupun mental siswa. Guru IPA dapat mengacu pada lima kunci agar pembelajaran IPA menjadi efektif, yaitu (1) melibatkan siswa dalam interaksi pembelajaran yang bermakna, (2) menciptakan lingkungan belajar yang kondusif agar pembelajaran penuh dengan toleransi dan disiplin, (3) memastikan siswa memperoleh arahan dengan tepat, (4) memiliki keterampilan bertanya untuk meningkatkan pemahaman siswa dan (5) membantu siswa utuk meningkatkan kepekaan terhadap pengalaman siswa agar memiliki kemampuan menghubungkan konsep-konsep penting dalam pembelajaran IPA.

Berdasarkan pengamatan di lokasi penelitian yaitu di SMP Santa Maria Fatima, selama ini kecenderungan proses pembelajaran IPA hanya terfokus dalam kemampuan siswa untuk menghafal saja, tetapi kenyataannya mereka tidak memahami secara mendalam substansi materinya. Hal tersebut diungkapkan siswa lewat angket yang diberikan peneliti. Hal senada juga diungkapkan oleh guru IPA sendiri (saat wawancara dengan peneliti) yang menyatakan bahwa pembelajaran IPA seringkali diupayakan untuk memenuhi standar nilai Kriteria Ketuntasan Minimal (KKM). Hal tersebut karena materi IPA yang cukup banyak sedangkan alokasi waktu yang sempit, memungkinkan guru dalam penyampaian materi tidak maksimal karena dikejar oleh waktu yang mengharuskan terselesaikannya materi. Penggunaan metode pembelajaran IPA yang terjadi ternyata juga belum berpijak pada konsep-konsep belajar. Hal tersebut diungkapkan oleh guru yang menyatakan bahwa sebagian besar metode pembelajaran yang digunakan adalah metode ceramah atau masih menekankan pada guru sebagai pusat pembelajaran. Jarang sekali guru menggunakan variasi metode pembelajaran mengingat alokasi waktu yang terbatas. Akibatnya, proses belajar tidak terjadi dengan maksimal karena siswa kurang terlibat aktif dalam perolehan informasi materi pelajaran.

Pembelajaran di sekolah yang bersifat klasikal melibatkan perbedaan indivi$\mathrm{du}$, karena setiap siswa merupakan individual yang unik. Setiap siswa memiliki perbedaan karakteristik satu dengan yang lain. Dalam Teknologi Pembelajaran (Seels dan Richey, 1994, p.35) karakteristik siswa merupakan salah satu variabel dalam domain desain pembelajaran. Karakteristik siswa adalah segi-segi latar belakang pengalaman siswa yang berpengaruh terhadap keefektifan proses belajar.

Latar belakang siswa, pengalaman yang dimiliki siswa termasuk aspek-aspek yang ada pada diri siswa mereka seperti kemampuan umum, tingkat kecerdasan, gaya belajar, motivasi, ekspektasi terhadap belajar, ciri-ciri jasmani serta emosional yang memberikan dampak terhadap keefektifan belajar. Salah satu karakteristik 
siswa yang mempengaruhi keefektifan belajar adalah gaya belajar. Gaya belajar siswa, adalah bagaimana siswa menyerap informasi yang diberikan oleh guru dan bagaimana siswa mengatur serta mengolah informasi tersebut. Dalam proses menyerap informasi, siswa dapat melibatkan tiga modalitas, yaitu visual, auditori, dan kinestetik. Setiap siswa pada dasarnya menggunakan ketiga modalitas tersebut dalam menyerap informasi. Namun, setiap siswa memiliki satu gaya belajar yang paling dominan diantara ketiga modalitas tersebut.

Guru diharapkan memahami gaya belajar siswanya agar dapat memfasilitasi lingkungan belajar yang sesuai dengan gaya belajar mereka. Dengan memahami gaya belajar siswa, guru akan terbantu untuk dapat merancang metode pembelajaran yang bervariasi yang sesuai dengan gaya belajar siswa yang beragam. Dengan demikian, semua atau sebagian besar siswa akan terlayani dalam proses belajarnya. Namun kenyataannya di lapangan, pihak sekolah menyatakan belum pernah melakukan identifikasi gaya belajar siswanya.

Identifikasi ini sangat penting dilakukan sebelum proses pembelajaran, karena dapat menjadi pijakan guru dalam melakukan proses pembelajaran. Adanya perbedaan gaya belajar siswa yang beragam tampak menjadi kendala dalam proses pembelajaran. Hal ini dinyatakan guru IPA, saat proses pembelajaran berlangsung sering terjadi hanya beberapa siswa saja yang mampu menangkap materi pelajaran dengan maksimal. Hal ini karena tidak semua siswa memperhatikan dengan baik saat guru menerangkan. Hal tersebut karena siswa tidak nyaman dengan mendengarkan ceramah/penjelasan guru. Dari uraian di atas, tampak bahwa salah satu persoalan yang muncul adalah pada perbedaan gaya belajar siswa dalam kelas. Terdapat siswa yang memiliki gaya belajar visual, auditori, maupun kinestetik.

Beberapa uraian permasalahan di atas mengakibatkan rendahnya pemahaman konsep terhadap materi pelajaran IPA. Hal ini juga ditunjukkan pada hasil belajar yang tampak dari data nilai siswa yang sebagian besar siswa mendapat nilai di bawah kriteria ketuntasan minimal. Berdasarkan data nilai yang peneliti peroleh, rata-rata nilai ujian IPA untuk empat tahun terakhir adalah yang terendah bila dibandingkan dengan nilai mata pelajaran lainnya.

Berdasarkan permasalahan di atas, peneliti melihat bahwa pembelajaran IPA membutuhkan sebuah metode yang mampu mengakomodir gaya belajar siswa yang beragam (visual, auditori, dan kinestetik), sehingga materi dapat terserap secara maksimal oleh semua siswa. Maka, diharapkan dengan metode tersebut dapat meningkatkan pemahaman konsep siswa. Peneliti akan menerapkan metode pembelajaran yang diduga dapat meningkatkan pemahaman konsep siswa, yaitu dengan metode pembelajaran mind mapping. Dalam metode pembelajaran mind mapping, guru dapat berkomunikasi timbal balik dengan siswa, misalnya dalam bentuk pengidentifikasian konsep, siswa dapat mengungkapkan ide, dan guru yang mengelola (Budd, 2003, p.2).

Penggunaan mind mapping di sini dimaksudkan untuk mempermudah pengusaan materi pada pembelajaran IPA di SMP. Di mana siswa tidak hanya sekedar menghafal tetapi dapat memahami. Metode ini efektif dan efisien, karena guru tidak perlu menggunakan modul dan tambahan waktu/pengayaan, waktu penyajianpun dapat dipersingkat mengingat materi IPA SMP sangat banyak, sedangkan alokasi waktunya sedikit. Pembelajaran dengan menggunakan peta pikiran (mind map) dimaksudkan agar siswa mudah dalam penguasaan materi. Dengan menyusun sendiri peta pikiran, siswa akan lebih memahami keterkaitan antarkonsep. Dengan peta pikiran juga mendorong siswa untuk mencari kaitan (asosiasi) di antara informasi dan membantu memilah dengan benar.

Mind mapping dapat membantu menyusun dan menyimpan sebanyak mungkin informasi yang diinginkan siswa, serta mengelompokkannya dengan cara yang alami, memberi akses yang mudah dan langsung seperti yang siswa inginkan. Mind mapping juga bersifat unik, karena se- 
suatu yang bersifat unik akan lebih mudah diingat siswa. Keunikan mind mapping terjadi karena setiap manusia termasuk anakanak mempunyai pancaran (pola pikir, imaginasi, pemahaman, kreatifitas, mengolah informasi) pikiran yang berbeda-beda (Swadarma, 2013, p.3).

Pembelajaran dengan mind mapping dapat mengoptimalkan semua modalitas, yaitu visual, auditori dan kinestetik. Sehingga pembelajaran dapat mengakomodir gaya belajar siswa visual, auditori, dan kinestetik. Melalui mind mapping, siswa tidak hanya mendengar penjelasan dari guru, tetapi ikut berperan aktif dalam proses pembelajaran supaya lebih memahami dan menguasai materi. Mind mapping dalam pembelajaran digunakan karena berpijak pada karakteristik siswa pada usia SMP.

Menurut Piaget (Phillips, Jr, 1969, p.11), pada usia ini siswa pada tahap operasional formal. Pada tahap ini siswa dapat berpikir secara abstrak dan logis. Siswa dapat beroperasi dengan logika dari kebebasan argumen. Sedangkan menurut Bruner $(1979$, p.36), anak usia remaja (SMP) merupakan tahap simbolik. Pada tahap ini siswa telah mampu memiliki ide-ide atau gagasan abstrak yang dipengaruhi oleh kemampuannya dalam berbahasa dan logika. Dalam memahami dunia sekitarnya, siswa belajar melalui simbol-simbol bahasa, logika, matematika, dan sebagainya. Komunikasinya dilakukan dengan menggunakan banyak sistem simbol. Semakin matang seorang anak dalam proses berpikirnya, semakin dominan sistem simbolnya.

Berdasarkan uraian latar belakang masalah di atas, maka peneliti melaksanakan penelitian tentang pengaruh mind mapping dan gaya belajar terhadap pemahaman konsep siswa dalam pembelajaran IPA SMP kelas VII. Sebagai kontrolnya digunakan kelas yang menggunakan metode ceramah. Metode ceramah yang digunakan menggunakan kombinasi dengan presentasi menggunakan power point. Metode ceramah dan presentasi dengan power point ini adalah metode yang biasa sering digunakan oleh guru IPA dalam proses pembelajaran.
Metode mind mapping dalam penelitian ini adalah metode dengan memetakan pikiran siswa. Pemetaan pikiran siswa difasilitasi oleh guru. Guru menjelaskan materi dengan membuat pusat mind map kemudian cabang-cabang mind map dilanjutkan oleh siswa kemudian siswa membuat mind map dengan bahasa/argumen sendiri yang kemudian dipresentasikan di depan kelas sesuai dengan pemetaan yang ada di pikiran siswa. Adapun tahapannya adalah pendahuluan, pemetaan pikiran (membuat mind map dengan diskusi dan tanya jawab), summarizing dengan membuat mind map, latihan dan umpan balik, melakukan percobaan/praktik, dan refleksi (presentasi mind map).

Metode ceramah dan presentasi merupakan metode yang dalam menyampaikan materi menggunakan presentasi dengan power point. Siswa mendengarkan dan dihimbau mencatat materi yang diterangkan oleh guru. Adapun tahapannya adalah pendahuluan, penyampaian materi dengan presentasi menggunakan power point, praktik, dan penampilan hasil.

Gaya belajar dalam penelitian ini adalah kemampuan siswa dalam menyerap informasi melalui modalitas visual, auditori, dan kinestetik dalam pelajaran IPA. Gaya belajar siswa dapat diidentifikasi menggunakan tes identifikasi gaya belajar yang diadaptasi dari tes gaya belajar de Porter dan Hernacki.

Pemahaman konsep dalam penelitian ini adalah kemampuan siswa dalam menginterpretasi, mengklasifikasi, mengidentifikasi, membuat pola, dan mengungkapkan kembali bagaimana sifat kimia dan fisika serta terjadinya perubahan fisika dan kimia. Pemahaman konsep siswa dapat diukur dengan tes pemahaman konsep.

Adapun tujuan dari penelitian ini adalah (1) mengetahui ada tidaknya perbedaan pemahaman konsep IPA antara siswa yang melaksanakan pembelajaran dengan metode mind mapping dengan siswa yang menggunakan metode ceramah dan presentasi, (2) mengetahui ada tidaknya perbedaan pemahaman konsep IPA antara siswa dengan gaya belajar visual, 
auditori, dan kinestetik, dan (3) mengetahui apakah terdapat pengaruh antara metode pembelajaran mind mapping dengan gaya belajar terhadap pemahaman konsep IPA siswa.

\section{Metode Penelitian}

Penelitian ini menggunakan metode eksperimen semu (quasi-experimental research). Rancangan yang digunakan dalam penelitian ini menggunakan rancangan pretes-postes Nonequivalent Control Group Design (Tuckman, 1972, pp.117-118). Model tersebut dapat divisualkan dalam bentuk diagram pada Gambar 1.

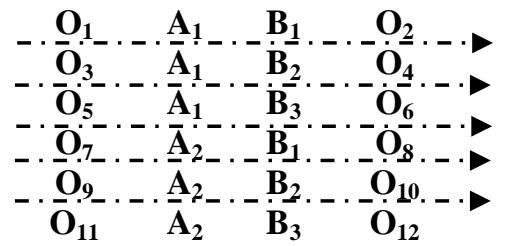

Gambar 1. Model Rancangan pretes-postes, Nonequivalent Control Group Design

Keterangan:

$\mathrm{O}_{1,3,5,7,9,11: \text { pretes }}$

$\mathrm{O}_{2,4,6,8,10,12: \text { postes }}$

$\mathrm{A}_{1}$ : Metode pembelajaran mind mapping

$\mathrm{A}_{2}$ :Metode pembelajaran ceramah dan presentasi

$\mathrm{B}_{1}$ : Kelompok siswa dengan gaya belajar visual

$\mathrm{B}_{2}$ :Kelompok siswa dengan gaya belajar auditori

$\mathrm{B}_{3}:$ Kelompok siswa dengan gaya belajar kinestetik.

Pada desain ini, data pemahaman konsep diperoleh melalui nilai pretes dan postes. Kedua kelompok masing-masing diberi pretes dan setelah proses pembelajaran diberikan postes. Dalam penelitian ini akan diberikan dua perlakuan yaitu metode mind mapping pada kelas eksperimen dan metode ceramah dengan presentasi pada kelas kontrol.

Tempat dilaksanakannya penelitian adalah di SMP Santa Maria Fatima Jakarta Timur. Waktu penelitian dilaksanakan pada semester genap tahun ajaran 2012/2013, pada bulan Mei 2013.

Populasi dari penelitian adalah seluruh siswa kelas VII SMP Santa Maria Fatima tahun ajaran 2012/2013 yang terdiri dari 4 kelas. Seluruh siswa berjumlah 155 siswa. Dalam penentuan sampel untuk kelas eksperimen dan kelas kontrol dilakukan dengan cluster sampling. Pengambilan sampel dengan cluster sampling adalah melakukan randomisasi terhadap kelompok, bukan terhadap subjek individual. Teknik yang digunakan adalah dengan pengundian. Hasil undian diperoleh kelas VIIA dengan jumlah 40 siswa sebagai kelas eksperimen dan kelas VIIB dengan jumlah 38 siswa sebagai kelas kontrol. Dari hasil pengundian tersebut maka kelas VIIA sebagai kelas eksperimen akan mendapat perlakuan dengan metode mind mapping. Sedangkan kelas VIIB sebagai kelas kontrol akan mendapat perlakuan dengan metode ceramah dan presentasi.

Desain yang digunakan dalam penelitian ini adalah desain faktorial $2 \times 3$ (Tuckman, 1972). Desain faktorial membagi kelompok-kelompok sesuai jumlah yang telah ditentukan berdasarkan jumlah perlakuan dan kelompok yang diteliti (Kerlinger, 1994, p.395). Berdasarkan hal tersebut, rancangan eksperimen faktorial 2x3 digunakan dalam penelitian ini. Dengan rancangan tersebut, akan dapat ditentukan pengaruh utama (main effect) dan pengaruh interaksi (interaction effect) dari variabel perlakuan. Adapun desain faktorial $2 \times 3$ dalam Tabel 1.

Tabel 1. Desain faktorial 2x3

\begin{tabular}{lll} 
Gaya & $\begin{array}{c}\text { Eelas (A) } \\
\text { Belajar (B) }\end{array}$ & $\begin{array}{c}\text { Kontrol } \\
\left(\mathrm{A}_{1}\right)\end{array}$ \\
\hline Visual $\left(\mathrm{B}_{1}\right)$ & $\mathrm{A}_{1} \mathrm{~B}_{1}$ & $\mathrm{~A}_{2} \mathrm{~B}_{1}$ \\
Auditori $\left(\mathrm{B}_{2}\right)$ & $\mathrm{A}_{1} \mathrm{~B}_{2}$ & $\mathrm{~A}_{2} \mathrm{~B}_{2}$ \\
Kinestetik $\left(\mathrm{B}_{3}\right)$ & $\mathrm{A}_{1} \mathrm{~B}_{3}$ & $\mathrm{~A}_{2} \mathrm{~B}_{3}$ \\
\hline
\end{tabular}

Keterangan:

$\mathrm{A}_{1} \mathrm{~B}_{1}$ : pemahaman konsep siswa yang memiliki gaya belajar visual menggunakan metode mind mapping

$\mathrm{A}_{1} \mathrm{~B}_{2}$ : pemahaman konsep siswa yang memiliki gaya belajar auditori menggunakan metode mind mapping

$\mathrm{A}_{1} \mathrm{~B}_{3}$ : pemahaman konsep siswa yang memiliki gaya belajar kenestetik menggunakan metode mind mapping 
$\mathrm{A}_{2} \mathrm{~B}_{1}$ : pemahaman konsep siswa yang memiliki gaya belajar visual menggunakan metode ceramah dan presentasi

$\mathrm{A}_{2} \mathrm{~B}_{2}$ : pemahaman konsep siswa yang memiliki gaya belajar auditori menggunakan metode ceramah dan presentasi

$\mathrm{A}_{2} \mathrm{~B}_{3}$ : pemahaman konsep siswa yang memiliki gaya belajar kenestetik menggunakan metode ceramah dan presentasi

Berdasarkan Tabel 1 menunjukkan bahwa variabel metode pembelajaran yang digunakan sebagai perlakuan penelitian memiliki dua dimensi, yaitu metode mind mapping $\left(\mathrm{A}_{1}\right)$ dan metode ceramah dan presentasi $\left(\mathrm{A}_{2}\right)$. Sedangkan variabel kelompok gaya belajar memiliki 3 dimensi, yaitu kelompok siswa dengan gaya balajar visual $\left(\mathrm{B}_{1}\right)$, kelompok siswa dengan gaya balajar auditori $\left(\mathrm{B}_{2}\right)$, dan kelompok siswa dengan gaya balajar kinestetik $\left(\mathrm{B}_{3}\right)$.

Dalam penelitian ini data yang digunakan adalah data gaya belajar siswa dan data pemahaman konsep siswa. Untuk mengetahui gaya belajar siswa menggunakan tes identifikasi gaya belajar siswa dan pengamatan gaya belajar siswa. Sedangkan untuk mengetahui pemahaman konsep siswa menggunakan tes pemahaman konsep (pretes dan postes)

Tes identifikasi gaya belajar siswa dilakukan untuk mengidentifikasi gaya belajar siswa: visual, auditori, dan kinestetik. Instrumen yang digunakan adalah angket gaya belajar. Angket yang digunakan oleh peneliti diadaptasi dari de Porter dan Reardon (2000, pp.166-167). Bentuk adaptasi yang dilakukan diantaranya (1) perubahan pada beberapa kalimat untuk disesuaikan bahasanya agar mudah dimengerti oleh siswa SMP, (2) perubahan pilihan jawaban yang semula tiga pilihan (selalu, kadang-kadang, dan jarang) menjadi dua pilihan (ya dan tidak), dengan alasan agar hasil dari tes tampak jelas perbedaan dari masing-masing gaya belajar, dan (3) perubahan urutan butir supaya tidak terbaca pola jawabannya. Subjek dari tes ini adalah siswa kelas VII pada kelompok eksperimen dan kelompok kontrol.

Pengamatan gaya belajar siswa dilakukan untuk mengkroscek gaya belajar siswa hasil dari angket gaya belajar. Instrumen yang digunakan adalah pedoman pengamatan gaya belajar. Pedoman pengamatan yang digunakan oleh peneliti adalah hasil modifikasi dari tes gaya belajar oleh de Porter dan Reardon (2000, pp.166167). Pengamatan gaya belajar ini dilakukan oleh dua orang pengamat, masingmasing untuk kelas eksperimen dan kelas kontrol. Pengamatan ini dilaksanakan sebelum proses perlakuan dilakukan.

Tes pemahaman konsep dilakukan dua kali yaitu sebagai pretes dan postes. Instrumen yang digunakan dalam tes pemahaman konsep adalah lembar tes pretes dan postes. Tes dilaksanakan di awal perlakuan (pretes), dan diakhir perlakuan (postes). Bentuk dari tes ini adalah objektif dengan 4 butir pilihan jawaban, dengan materi soal yang diambil dari materi yang ada pada pokok bahasan, yaitu "Sifat dan Perubahan Materi". Subjek dari tes ini adalah siswa kelas VII pada kelompok eksperimen dan kelompok kontrol.

Penyusunan soal diawali dengan pembuatan kisi-kisi soal, kemudian menyusun soal. Kisi-kisi pada tes ini mengacu pada aspek-aspek indikator pemahaman konsep menurut Anderson \& Krathwohl (2001, p.67), yaitu (1) Interpreting: mampu mengubah informasi ke dalam bentuk representasi yang lain, misalnya kata menjadi gambar, gambar menjadi kata, kata menjadi bilangan, dan lain-lain. (2) Exemplifying: mampu memberikan contoh tentang konsep-konsep yang sedang dipelajari. (3) Classifying: mampu mengklasifikasikan konsep-konsep umum menjadi kategori yang lebih spesifik dan mampu mendeteksi hubungan antara kategori tersebut. (4) Summarizing: mampu mempresentasikan sebuah pernyataan atau informasi dengan bahasa sendiri dari materi/konsep yang sudah dipelajari. (5) Inferring: mampu menemukan sebuah pola antara konsep dengan atribut/ contohnya. (6) Comparing: mampu mengidentifikasi kemiripan dan perbedaan antara dua atau lebih konsep/ide/masalah. (7) Explaining: mampu membentuk dan menjelaskan bagaimana sebab akibat dari suatu konsep. 
Pretes digunakan untuk mengetahui kemampuan awal atau sejauh mana pemahaman konsep siswa sebelum perlakuan. Postes diberikan untuk mengetahui sejauh mana pemahaman konsep siswa setelah perlakuan. Kegiatan dokumentasi juga dilakukan oleh peneliti. Instrumen yang digunakan diantaranya adalah catatan lapangan dan kamera. Data dari dokumentasi ini digunakan untuk mendukung data-data yang diperoleh dari hasil tes identifikasi gaya belajar, pengamatan gaya belajar, dan tes pemahaman konsep.

Analisis deskripsi bertujuan untuk memberikan deskripsi mengenai subjek penelitian berdasarkan data dari variabel yang diperoleh dari kelompok penelitian. Langkah-langkah yang dilakukan pada tahap deskripsi data pemahaman konsep siswa adalah membuat tabulasi data, mengurutkan data secara interval, dan menyusunnya dalam bentuk tabel distribusi frekuensi. Kemudian dilanjutkan dengan mencari modus, median, rata-rata/mean, dan simpangan baku. Deskripsi data dihitung menggunakan program Microsoft Office Excel 2007.

Pengujian hipotesis didahului dengan melakukan uji prasyarat, yaitu dengan uji normalitas dan uji homogenitas. Uji normalitas bertujuan untuk mengetahui apakah data yang diperoleh berdistribusi normal atau tidak. Uji normalitas dilakukan pada data pretes dan postes kelas eksperimen dan kelas kontrol. Uji normalitas menggunakan uji Shapiro-Wilk dengan bantuan program SPSS versi 16 for Windows. Uji homogenitas bertujuan untuk mengetahui kesamaan varian-varian yang berasal dari populasi yang sama. Uji homogenitas menggunakan uji Lavene dengan bantuan program SPSS versi 16 for Windows.

Untuk pengujian hipotesis dalam penelitian ini menggunakan analisis varians (Anova) dua arah dengan tingkat signifikansi 5\%. Perhitungan untuk uji hipotesis dilakukan dengan bantuan program SPSS versi 16 for Windows. Adapun uji hipotesis dalam penelitian ini adalah sebagai berikut: (1) menguji adanya perbedaan pemahaman konsep IPA pada pembelajaran antara siswa yang melaksanakan pembelajaran dengan metode mind mapping dengan metode ceramah dan presentasi; (2) menguji adanya perbedaan pemahaman konsep IPA siswa dengan gaya belajar visual, auditori, dan kinestetik; (3) menguji adanya pengaruh antara metode pembelajaran mind mapping dengan gaya belajar terhadap pemahaman konsep siswa.

\section{Hasil Penelitian dan Pembahasan}

\section{Deskripsi Data Gaya Belajar Siswa}

Perolehan data angket gaya belajar yang disebar pada 78 siswa (kelas 7A sejumlah 40 siswa dan kelas 7B sejumlah 38 siswa), didapatkan bahwa gaya belajar visual adalah gaya belajar yang paling banyak dimiliki siswa yaitu sebanyak 32 siswa. Sedangkan, untuk gaya belajar auditori sebanyak 27 siswa dan gaya belajar kinestetik sebanyak 19 siswa. Adapun data gaya belajar siswa disajikan pada Tabel 2 .

Tabel 2. Deskripsi Hasil Gaya Belajar Siswa

\begin{tabular}{ccccc}
\hline $\begin{array}{c}\text { Gaya } \\
\text { Belajar }\end{array}$ & $\begin{array}{c}\text { Kelas } \\
\text { Eksperimen }\end{array}$ & $\begin{array}{c}\text { Kelas } \\
\text { Kontrol }\end{array}$ & Jumlah & Prosentase \\
\hline Visual & 17 & 15 & 32 & $41,03 \%$ \\
Auditori & 14 & 13 & 27 & $34,62 \%$ \\
Kinestetik & 9 & 10 & 19 & $24,36 \%$ \\
Jumlah & 40 & 38 & 78 & $100,00 \%$ \\
\hline
\end{tabular}

Berdasarkan Tabel 2 dapat diketahui bahwa kecenderungan gaya belajar siswa kelas 7A dan 7B SMP Santa Maria Fatima tahun pelajaran 2012/ 2013 adalah gaya belajar visual. Untuk melihat perbandingan gaya belajar secara keseluruhan dapat dilihat pada Gambar 2.

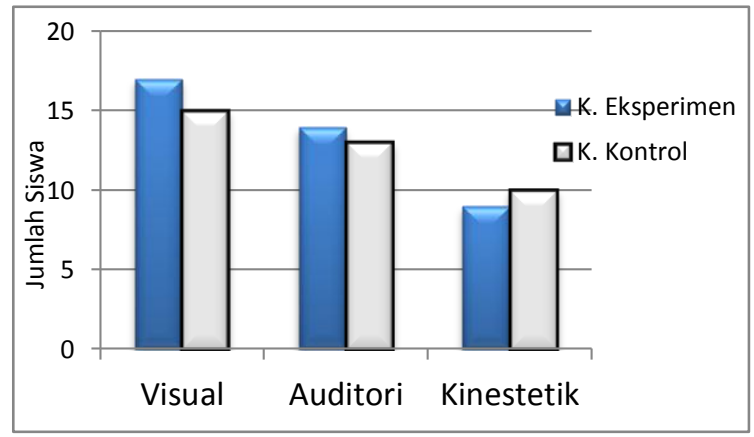

Gambar 2. Diagram Perbandingan Gaya Belajar Siswa 
Pada Gambar 2, menunjukkan bahwa gaya belajar visual kelas eksperimen lebih besar dibanding kelas kontrol. Gaya belajar auditori kelas eksperimen lebih besar daripada kelas kontrol. Sedangkan, untuk gaya belajar kinestetik kelas eksperimen lebih kecil dibanding kelas kontrol.

Deskripsi Data Hasil Pemahaman Konsep Siswa

Hasil analisis deskripsi pemahaman konsep siswa ditunjukkan pada Tabel 3.

Tabel 3. Deskripsi Hasil Pemahaman Konsep Siswa

\begin{tabular}{|c|c|c|c|c|c|}
\hline \multirow{2}{*}{ No } & \multirow{2}{*}{ Deskripsi } & \multicolumn{2}{|c|}{$\begin{array}{c}\text { Kelas } \\
\text { Eksperimen }\end{array}$} & \multicolumn{2}{|c|}{$\begin{array}{c}\text { Kelas } \\
\text { Kontrol }\end{array}$} \\
\hline & & pretes & postes & pretes & postes \\
\hline 1 & Mean & 44.4375 & 68.25 & 42.5 & 55.395 \\
\hline 2 & Median & 42.5 & 67.5 & 42.5 & 52.5 \\
\hline 3 & Modus & 37.5 & 65 & 42.5 & 52.5 \\
\hline 4 & Std deviasi & 10.689 & 10.863 & 9.621 & 11.516 \\
\hline 5 & Varians & 114.259 & 118.013 & 92.568 & 132.61 \\
\hline 6 & Nilai minimum & 25 & 47.5 & 27.5 & 37.5 \\
\hline 7 & Nilai maksimum & 62.5 & 90 & 65 & 82.5 \\
\hline 8 & Ketuntasan & 0 & 28 & 1 & 9 \\
\hline
\end{tabular}

Perbandingan nilai sesudah perlakuan secara keseluruhan, dapat dilihat pada Gambar 3.

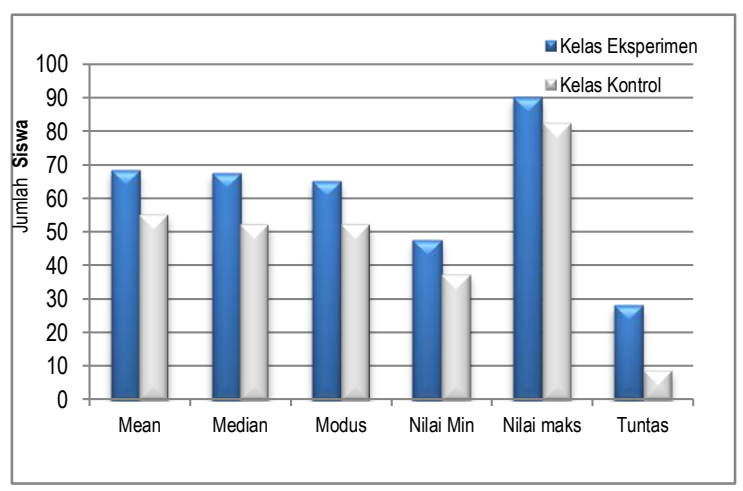

Gambar 3. Diagram Perbandingan Hasil

Pemahaman Konsep Siswa sesudah Perlakuan.

Pada Gambar 3 menunjukkan bahwa mean, median, modus, nilai minimal, nilai maksimal, dan tingkat ketuntasan siswa pada kelas eksperimen lebih tinggi dibanding pada kelas kontrol.
Data Hasil Pemahaman Konsep Siswa pada Masing-masing Kelompok Gaya Belajar.

Data hasil pemahaman konsep siswa dikelompokkan menjadi 6 kelompok sesuai dengan desain faktorial $2 \times 3$ yaitu 3 kelompok pada kelas eksperimen dan 3 kelompok pada kelas kontrol. Data selengkapnya dapat dilihat pada Tabel 4.

Tabel 4. Deskripsi Hasil Pemahaman Konsep Siswa pada Masing-masing Kelompok Gaya Belajar

\begin{tabular}{cccc}
\hline Kelompok & Mean & $\begin{array}{c}\text { Std } \\
\text { deviasi }\end{array}$ & $\begin{array}{c}\text { Jml siswa } \\
\text { tuntas }\end{array}$ \\
\hline $\mathrm{A}_{1} \mathrm{~B}_{1}$ & 65.88 & 19.5 & 11 \\
$\mathrm{~A}_{1} \mathrm{~B}_{2}$ & 69.11 & 11.71 & 11 \\
$\mathrm{~A}_{1} \mathrm{~B}_{3}$ & 65.561 & 7.48 & 6 \\
$\mathrm{~A}_{2} \mathrm{~B}_{1}$ & 55.5 & 12.72 & 5 \\
$\mathrm{~A}_{2} \mathrm{~B}_{2}$ & 56.92 & 11.99 & 3 \\
$\mathrm{~A}_{2} \mathrm{~B}_{3}$ & 53.25 & 10.54 & 1 \\
\hline
\end{tabular}

Pada Tabel 4 terlihat bahwa mean kelompok siswa dengan gaya belajar visual yang menggunakan metode mind mapping $\left(\mathrm{A}_{1} \mathrm{~B}_{1}\right)$ lebih tinggi dari kelompok siswa dengan gaya belajar visual yang menggunakan metode ceramah dan presentasi $\left(\mathrm{A}_{2} \mathrm{~B}_{1}\right)$. Nilai mean kelompok siswa dengan gaya belajar auditori yang menggunakan metode mind mapping $\left(\mathrm{A}_{1} \mathrm{~B}_{2}\right)$ lebih tinggi dari kelompok siswa gaya belajar auditori yang menggunakan metode ceramah dan presentasi $\left(\mathrm{A}_{2} \mathrm{~B}_{2}\right)$. Nilai mean kelompok siswa dengan gaya belajar kinestetik yang menggunakan metode mind mapping $\left(\mathrm{A}_{1} \mathrm{~B}_{3}\right)$ lebih tinggi dari kelompok siswa gaya belajar kinestetik yang menggunakan metode ceramah dan presentasi $\left(\mathrm{A}_{2} \mathrm{~B}_{3}\right)$. Perbandingan nilai mean pemahaman konsep kelas eksperimen dan kelas kontrol dapat dilihat pada Gambar 4.

Pada Gambar 4 menunjukkan bahwa mean tertinggi pada kelas eksperimen yang menggunakan metode mind mapping adalah pada kelompok siswa dengan gaya belajar auditori. Hal yang sama juga terjadi pada kelas kontrol yang menggunakan metode ceramah dan presentasi adalah pada kelompok siswa dengan gaya belajar auditori. 


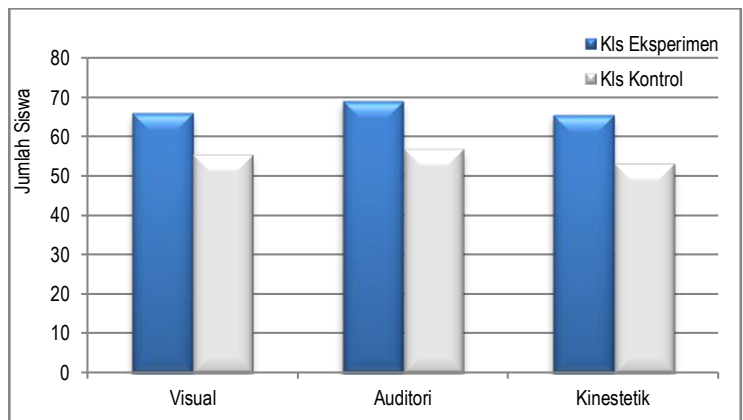

Gambar 4. Diagram Perbandingan Nilai Mean Pemahaman Konsep Siswa pada Kelas Eksperimen dan Kelas Kontrol

Pembahasan

Pengaruh Metode Pembelajaran terhadap Pemahaman Konsep Siswa

Metode pembelajaran merupakan teknik yang diterapkan oleh guru dalam proses belajar mengajar untuk mencapai tujuan pembelajaran. Melalui metode yang tepat akan menyebabkan siswa merasa nyaman dan dapat berkonsentrasi dalam proses pembelajaran. Siswa akan merasa ada kecocokan antara proses di luar dan di dalam dirinya, hal ini menyebabkan proses pembelajaran menjadi aktif dan menyenangkan. Oleh sebab itu, pemilihan metode pembelajaran sebaikanya merupakan kombinasi berbagai metode yang disesuaikan dengan tujuan pembelajaran, karakteristik siswa, dan karakteristik materi pelajaran yang akan disampaikan.

Kegiatan dalam pembelajaran dengan metode tertentu diharapkan tumbuh sebagai kegiatan yang menciptakan interaksi edukatif. Proses interaksi akan berjalan dengan baik jika banyak siswa yang aktif dibandingkan dengan guru. Oleh karena itu metode pembelajaran yang baik adalah metode yang dapat menumbuhkan keaktifan siswa untuk mencari dan menemukan sendiri konsep-konsep pada materi pelajaran, sehingga siswa dapat membentuk pemahaman konsepnya sendiri.

Pemahaman konsep pada siswa akan terbentuk jika siswa mampu mengkontruksikan makna pesan-pesan dari pengajaran seperti komunikasi lisan, tulisan dan grafik. Siswa mampu memahami suatu pengetahuan yang baru diintegrasikan ter- sebut dengan skema dan kognitif yang sudah ada padanya.

Dalam penelitian ini, sebelum diberikan perlakuan, hasil pretes menunjukkan bahwa nilai rata-rata pemahaman konsep siswa pada kelas kontrol adalah 42,5 dan pada kelas eksperimen adalah 44,4. Hal tersebut menunjukkan bahwa semua subjek (78 siswa), pemahaman konsepnya berada pada kategori sedang. Fakta ini menunjukkan bahwa para siswa belum memiliki pemahaman konsep sebagaimana yang diharapkan, karena masih berada di bawah nilai KKM yaitu 65. Setelah pelaksanaan perlakuan, secara kuantitatif terdapat peningkatan nilai rata-rata pemahaman konsep baik pada kelas eksperimen dan kelas kontrol. Nilai rata-rata yang diperoleh pada kelas kontrol adalah 55,4.

Nilai tersebut menunjukkan bahwa pemahaman konsep siswa pada kelas kontrol masih berada pada kategori sedang dan masih berada di bawah nilai KKM. Sedangkan nilai rata-rata yang diperoleh pada kelas eksperimen adalah 68,3. Nilai tersebut menunjukkan bahwa pemahaman konsep siswa pada kelas eksperimen berada pada kategori tinggi dan berada di atas nilai KKM. Adanya peningkatan kategori pemahaman konsep siswa pada kelas eksperimen dari sedang menjadi tinggi menunjukkan bahwa perlakuan metode pembelajaran mind mapping yang diterapkan memberikan pengaruh positif terhadap pemahaman konsep siswa.

Hasil uji statistik menunjukkan terdapat perbedaan pemahaman konsep siswa secara signifikan oleh metode pembelajaran. Hal ini ditunjukkan dengan uji Anova yang menunjukkan bahwa Ho ditolak dan Ha diterima, yang berarti hipotesis pertama dalam penelitian ini teruji kebenarannya dan dapat diterima. Dengan demikian penerapan metode pembelajaran menyebabkan perbedaan yang signifikan terhadap pemahaman konsep siswa. Kelompok siswa yang menggunakan metode pembelajaran mind mapping memiliki kemampuan pemahaman konsep lebih baik dari kelompok siswa yang menggunakan metode pembelajaran ceramah dan presentasi. 
Pembelajaran dengan metode mind mapping mampu memberikan daya ingat peserta didik lebih lama karena metode mind mapping dapat memaksimalkan kerja kedua belah otak. Hal ini tentunya memberikan memori yang lebih lama sehingga mampu mendapatkan informasi lebih cepat, karena dalam mind mapping siswa diberikan kesempatan untuk memahami konsep-konsep menggunakan gambar, simbol, warna, serta poin-poin kunci lainnya sesuai dengan kreativitas dan keinginannya sendiri.

Penggunaan gambar, simbol, warna, serta poin-poin kunci lainnya merangsang otak siswa untuk lebih cepat mengambil informasi dan menyimpan lebih lama. Metode mind mapping mampu meringkas materi yang dipelajari (baik yang dibaca siswa sendiri maupun yang dijelaskan oleh guru) kemudian menuangkan dalam bentuk gambar, sehingga siswa mendapat keuntungan untuk memahami materi dengan lebih mudah, cepat, dan lebih ringkas Yovan Putra (2008, pp.257-258).

Siswa pada umumnya menginginkan materi pelajaran yang diterima dalam proses belajar menjadi sebuah ingatan jangka panjang. Salah satu cara yang dilakukan sebagian besar siswa adalah mencatat semua materi yang didapat dalam proses belajar (hal ini dilakukan juga oleh siswa pada kelas kontrol). Tujuan pencatatan adalah membantu mengingat informasi yang tersimpan dalam memori tanpa mengulang informasi.

Kegiatan mencatat yang dilakukan siswa pada kelas kontrol merupakan catatan dalam bentuk tulisan linear panjang dan atau menyalin power point dari guru, sehingga catatan terlihat monoton dan membosankan. Hasil catatan yang kurang menarik atau kegiatan mencatat yang tidak berkesan memicu rasa jenuh siswa dalam belajar, yang tentunya hal ini sangat mempengaruhi siswa dalam memahami konsep materi pelajaran.

Pembelajaran dengan metode mind mapping juga dapat memberikan efek yang menyenangkan dan tidak monoton, sehingga siswa dapat lebih relaks. Misalnya saat akan membuat mind map, siswa diperbolehkan membuat di luar kelas (di perpustakaan, aula, taman, atau lapangan), sehingga tidak bosan di dalam kelas. Keadaan belajar yang santai dapat memicu siswa dengan kondisi emosional yang lebih baik dibandingkan kondis belajar dengan metode ceramah yang terkesan selalu sama sehingga relatif membuat siswa cepat jenuh dalam belajar. Perasaan tenang, nyaman, dan sangat mendukung siswa belajar dengan lebih berkesan akan memberikan pembelajaran yang berpengalaman (tidak mudah dilupakan oleh siswa). Skenario dalam metode mind mapping, siswa diminta untuk menuangkan semua ide-ide yang ada dalam otak mereka membentuk sebuah gambar. Kegiatan ini tentunya sangat berbeda jauh dibandingkan dengan metode ceramah yang lebih terfokus pada satu kegiatan mendengarkan, mencatat, ataupun berbicara seperlunya. Metode ceramah kurang mampu menciptakan kondisi belajar yang lebih variatif dan menyenangkan sehingga siswa cenderung bosan dalam belajar yang mengakibatkan pengaruh pada siswa untuk memahami konsep materi pelajaran.

Peningkatan pemahaman konsep dengan menggunakan metode mind mapping dibandingkan dengan metode ceramah dan presentasi antara lain karena beberapa faktor yang dapat meningkatkan pemahaman konsep siswa, diantaranya:

\section{Kondisi belajar yang lebih menyenangkan}

Kondisi belajar yang relatif fleksibel mampu menciptakan suasana yang menyenangkan. Siswa tidak merasa menjalankan sesuatu yang diatur, sebaliknya siswa diberikan kebebasan untuk mengekspresikan pemikiran dan imajinasi mereka terhadap materi yang diperoleh, serta menuangkannya pada hasil mind mapping yang dibuat.

\section{Metode belajar yang lebih variatif}

Selain membuat mind map, dalam metode mind mapping juga terdapat beberapa kegiatan lain yang variatif yang dapat 
membantu siswa untuk memahami konsep materi pelajaran. Kegiatan tersebut diantaranya mendengarkan penjelasan guru dengan diskusi, menjawab pertanyaan guru, membuat mind map, mengerjakan lembar kerja dalam bentuk mind map, dan praktikum.

Menurut Wilis (2011, p.42), strategi penyampaian materi yang bervariasi (lebih dari satu cara) akan menyebabkan terbentuknya lebih banyak jalur yang menuntun kepada informasi baru yang tersimpan. Hal ini berarti akan ada lebih banyak cara untuk mengakses informasi yang nantinya dapat digunakan untuk pemanggilan kembali setelah disimpan di dalam pusat memori jangka panjang.

\section{Mampu menggali potensi siswa lebih maksimal}

Melalui mind mapping, guru berperan sebagai pengarah atau pembimbing agar pemahaman konsep siswa tidak ke luar dari konsep materi yang diajarkan. Pada pengerjaan mind mapping siswa diberi kesempatan yang bebas untuk berimajinasi dan menggali pikiran-pikiran atau ide-ide yang lebih baik sesuai dengan kreatifitas dan keingingannnya masing-masing.

\section{Memberikan daya ingat kepada siswa yang lebih lama}

Mind mapping dapat memberikan daya ingat yang lebih lama, hal ini dikarenakan dengan menggunakan mind mapping siswa mampu menangkap informasi-informasi yang diperoleh dari materi yang diberikan dan mengolahnya menjadi sebuah pemahmaan dengan cara yang lebih baik.

Pada kelas eksperimen yang menggunakan metode mind mapping, siswa dengan gaya belajar visual dapat menyerap materi dengan memperhatikan presentasi guru saat menjelaskan dengan mind mapping, memperhatikan mind map guru, dan mencatat/ membuat mind map. Pada saat proses ini berlangsung, stimulus (informasi materi pelajaran) yang diterima oleh indera tubuh siswa, yaitu mata/visual kemudian diteruskan menjadi persepsi. Persepsi me- rupakan tahap kognitif dimana siswa menyadari sensasi yang disebabkan oleh stimulus dan interpretasi informasi dari pengalaman atau pengetahuannya.

Proses persepsi terdiri dari dua tahap, yaitu deteksi dan rekognisi. Deteksi terjadi pada saat siswa menyadari adanya stimulus, dan rekognisi terjadi ketika siswa menginterpretasikan arti dari stimulus tersebut serta mengidentifikasinya dengan pengalaman/pengetahuan sebelumnya. Mind map merupakan alat bantu grafis yang membantu siswa untuk melihat hubungan dan pola dari informasi baru untuk disimpan dalam memori. Melalui mind mapping, memungkinkan siswa membuat koneksi, melihat pola, mengakses memori terkait yang telah tersimpan sebelumnya, dan mengembangkan jalur memori yang sudah ada sebelumnya (Wilis, 2011, p.22).

Bagi siswa dengan gaya belajar auditori dapat menyerap materi pelajaran dengan mendengarkan penjelasan guru, berdiskusi/mendengarkan diskusi, dan mengungkapkan secara verbal (presentasi) mind map yang telah dibuat. Siswa dengan gaya belajar auditori memiliki kelebihan dalam kemampuan verbal. Saat berdiskusi. Siswa dengan gaya belajar auditori tampak dominan dalam menyampaikan pendapatnya. Hal ini dapat membantu siswa tersebut dalam memahami materi pelajaran. Setelah siswa mendengar penjelasan dari guru, kemudian mengulang informasi dengan membuat mind map, maka terjadi proses pengulangan informasi pada otak.

Menurut Koutstaal, dkk dalam Wilis (2011, p.41), ketika otak menerima informasi yang diulang dalam beberapa cara, terdapat sebuah proses penyiagaan untuk mengkode informasi tersebut menjadi lebih efisien. Siswa dengan gaya belajar auditori pada saat menulis kata dalam mind map, kemudian mempresentasikannya di depan kelas, menyebabkan terjadinya penyimpanan memori jangka panjang dan pemanggilan kembali yang lebih baik daripada sekedar menghafal definisi sebuah kata.

Siswa dengan gaya belajar kinestetik dapat menyerap materi pelajaran dengan beraktivitas saat guru membuat mind 
map (maju dan menggambar peta dengan melanjutkan mind map), menggambar mind map sesuai kreativitasnya sendiri, dan saat melaksanakan praktikum. Bagi siswa dengan gaya belajar kinestetik, belajar akan lebih nyaman jika melibatkan fisik serta menggerakkan tubuh saat proses pembelajaran. Salah satu kegiatan siswa pada metode mind mapping adalah membuat mind map, dan ini dilakukan tidak hanya sekali.

Kegiatan membuat mind map ini melibatkan pergerakan tangan untuk membuat peta, jalur dan koneksi antar konsep. Proses pergerakan tangan yang terus-menerus untuk menghubungkan konsep ini dapat meningkatkan kerja otak pada siswa, sehingga kemampuan untuk memahami konsep pada materi pelajaran dapat berlangsung maksimal. Kegiatan praktikum di laboratorium yang melibatkan aktifitas gerak tubuh juga dapat membantu siswa dalam memahami materi pelajaran. Bagi siswa dengan gaya belajar kinestetik, semakin banyak gerak tubuh dalam proses belajar, maka akan semakin banyak informasi yang diperoleh. Hal ini karena isyarat tubuh dan gerakan dapat merangsang bertambahnya jalur untuk penyimpanan informasi (Sprenger, 2011, p.110).

Berdasarkan uraian di atas, maka penggunaan metode mind mapping berpengaruh terhadap pemahaman konsep IPA siswa. Hal ini ditunjukkan dengan pengaruh postif mind mapping sebesar 25,8\% mempengaruhi pemahaman konsep IPA siswa.

Pengaruh Gaya Belajar terhadap Pemahaman Konsep Siswa

Gaya belajar adalah cara menyerap informasi yang diperoleh kemudian mengatur, mengolah dan mengkonstruksikannya sesuai dengan pengalaman dan kebiasaan. Pada penelitian ini hanya dibatasi dari bagaimana siswa menyerap informasi, yaitu melalui tiga modalitas, diantaranya visual, auditori, dan kinestetik.

Gaya belajar sangat diperlukan dalam pembelajaran karena dengan modalitas siswa dapat menyerap informasi yang diperoleh kemudian mengatur dan mengolah informasi yang didapat dari proses belajar. Siswa yang memiliki gaya belajar visual biasanya lebih menyukai input visual. Siswa dengan gaya belajar auditori lebih suka masukan yang bersifat audio. Sedangkan siswa dengan gaya belajar kinestetik lebih menyukai masukan fisik, mereka ingin belajar tentang sesuatu dengan memanipulasi segala sesuatu dengan menyentuh, merasa, dan beraktivitas (de Porter \& Hernacki, 2008, p.112).

Sebuah metode pembelajaran yang mengoptimalkan gaya belajar akan menjadikan siswa merasa nyaman dalam belajar. Pembelajaran sebaiknya mementingkan pengalaman belajar secara langsung dan menyenangkan bagi siswa. Pengalaman belajar secara langsung didapat dengan cara belajar dengan melihat dan mengingat (visual), belajar dengan mendengar (auditori), dan belajar dengan gerak dan emosi (kinestetik). Ketika gaya belajar siswa dapat terakomodir dalam sebuah metode pembelajaran yang tepat, maka akan membantu siswa memahami materi pelajaran. Hal ini karena siswa dimudahkan dalam proses penyerapan informasi dari materi pelajaran tersebut. Semakin banyak informasi yang mampu diserap oleh siswa, maka akan semakin meningkat pula pemahaman konsep siswa tersebut.

Bagi siswa dengan gaya belajar visual, akan mudah menerima informasi dengan bantuan media dua dimensi seperti menggunakan grafik, gambar, chart, model, dan sejenisnya. Siswa dengan gaya belajar auditori, akan lebih mudah menerima informasi melalui pendengaran atau sesuatu yang diucapkan atau dengan media audio. Sedangkan siswa dengan gaya belajar kinestetik, akan mudah menerima informasi sambil melakukan kegiatan tertentu, misalnya eksperimen, bongkar pasang, membuat model, memanipulasi benda, dan sebagainya yang berhubungan dengan sistem gerak (Meier, 2000, p.90).

Hasil penelitian ini menunjukkan bahwa pemahaman konsep siswa tidak dipengaruhi oleh gaya belajar siswa. Hal ini ditunjukkan dengan uji Anova bahwa 
pemahaman konsep siswa yang memiliki gaya belajar visual tidak berbeda secara signifikan dengan siswa yang memiliki gaya belajar auditori maupun siswa yang memiliki gaya belajar kinestetik.

Hasil tersebut menunjukkan bahwa karakteristik siswa yang dilihat dari gaya belajarnya tidak memberikan pengaruh kepada hasil belajar siswa pada pemahaman konsep. Karakteristik siswa merupakan segi-segi latar belakang pengalaman siswa yang berpengaruh terhadap keefektifan proses belajar. Latar belakang siswa, pengalaman yang dimiliki siswa termasuk aspek-aspek yang ada pada diri siswa, seperti: kemampuan umum, tingkat kecerdasan, gaya belajar, motivasi, ekspektasi terhadap belajar, ciri-ciri jasmani serta emosional yang memberikan dampak terhadap keefektifan belajar (Seels \& Richey, 1994, p.35). Dari pengertian tersebut dan dari hasil penelitian ini menunjukkan bahwa gaya belajar bukan satu-satunya faktor karakteristik siswa yang dapat menentukan hasil belajar siswa, yaitu pemahaman konsep.

Tidak adanya pengaruh yang berbeda dari pengelompokkan berdasarkan gaya belajar terhadap pemahaman konsep dapat dijelaskan mengacu pada teori tentang gaya kognitif. Menurut Keefe dalam Riding (2002, p.22) gaya kognitif adalah bagian dari gaya belajar yang menggambarkan kebiasaan perilaku yang relatif tetap pada diri siswa dalam menerima, mengolah, dan menyimpan informasi. Suharjono dalam Asri Budiningsih (2004, p.68) menyatakan bahwa gaya kognitif terdiri dari dua dimensi, yaitu gaya dalam menerima informasi dan gaya dalam pembentukan konsep dan mengingat. Sehubungan dengan teori tersebut maka dalam penelitian ini tidak nampak perbedaan pemahaman konsep berdasarkan gaya belajar siswa. Hal ini karena dalam penelitian ini hanya dibatasi pada siswa menerima informasi dengan gaya belajarnya (melalui modalitas visual, auditori, dan kinestetik), untuk proses siswa dalam mengolah dan menyimpan informasi tidak diteliti dalam penelitian ini. Maka dalam penelitian ini menunjukkan tidak tampak perbedaan pemahaman konsep siswa berdasarkan modalitas belajarnya (visual, auditori, dan kinestetik). Tahap pengolahan dan penyimpanan informasi tidak diperhitungkan dalam penelitian ini, walaupun sebenarnya proses pengolahan dan penyimpanan informasi ini sangat berpengaruh pada pemahaman konsep siswa.

Pernyataan di atas juga sejalan dengan teori kognitif tentang pemrosesan informasi. Menurut Anderson (1980), pemrosesan informasi mengandung pengertian tentang bagaimana siswa mempersepsi, mengorganisasi, dan mengingat sejumlah besar informasi yang diterima individu dari lingkungan. Penerapan teori pengolahan informasi dalam belajar ada tiga tahapan yaitu (1) perhatian ke stimulus: pemrosesan sistem informasi dalam memori siswa di awali ketika isyarat fisik diterima pencatat sensor melalui indera (visual, audio, maupun kenestetik). Pada tahap ini modalitas bekerja. Isyarat fisik ini, kemudian disimpan sebentar untuk diolah dalam sistem memori, (2) mengkode stimulus: stimulus akan diproses sebagai informasi aktif atau akan lebih lanjut atau tidak sampai memori jangka panjang sebagai memori inaktif, maka diperlukan pengolahan lebih lanjut. Proses inilah yang disebut dengan pengkodean yaitu mengubah stimulus sehingga dapat disimpan sehingga pada waktu lain dapat di munculkan kembali dengan mudah, dan (3) penyimpanan dan retrieval: pengkodean dimaksudkan untuk menyimpan informasi guna disimpan dalam memori jangka panjang untuk dapat diingat sewaktu-waktu diperlukan. Untuk proses ini, sangat bergantung pada bagaimana informasi itu disimpan dan bagaimana hubungan informasi itu dengan informasi sebelumnya dari memori jangka panjang. Bentuk visualisasi dari pemrosesan informasi dapat dilihat pada Gambar 5.

Pada Gambar 5 terdapat tanda lingkaran merah yang menunjukkan proses modalitas bekerja. Pada penelitian ini, pemrosesan informasi yang diteliti hanya sampai pada tahap tersebut. Padahal siswa 
dapat memahami suatu materi melalui tahapan di atas. Sehingga hal ini dapat menunjukkan bahwa tidak tampak perbedaan yang signifikan pada pemahaman konsep siswa berdasarkan gaya belajarnya (modalitas visual, auditori, dan kinestetik).

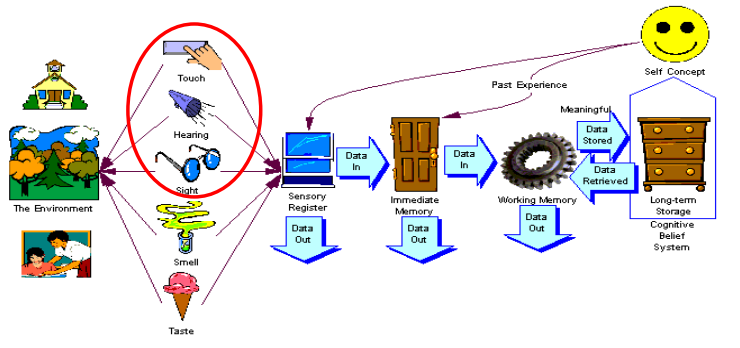

Gambar 5. Visualisasi Pemrosesan Informasi

Pengaruh Metode Pembelajaran dan Gaya Belajar terhadap Pemahaman Konsep Siswa

Pada penelitian ini, dengan uji Anova menunjukkan bahwa tidak ada pengaruh antara metode pembelajaran dan gaya belajar siswa terhadap pemahaman konsep siswa. Uji Anova yang menunjukkan bahwa Ho diterima dan Ha ditolak, yang berarti hipotesis kerja penelitian tidak teruji kebenarannya dan tidak dapat diterima.

Metode pembelajaran diduga berkaitan dengan gaya belajar yang dimiliki siswa. Ketika seorang guru dapat menerapkan suatu metode yang dapat mengakomodir semua gaya belajar siswa, maka dapat meningkatkan pemahaman konsep siswa. Metode pembelajaran yang tepat dapat membantu siswa agar mudah menyerap materi, harus juga diusahakan materi tersebut dapat diingat dalam jangka waktu yang lama agar konsep-konsep yang telah diperoleh dapat digunakan untuk memecahkan permasalahan dalam kehidupan sehari-hari. Dengan mengetahui gaya belajar siswa, seorang guru akan lebih mudah menyampaikan materi pelajaran dengan metode pembelajaran yang sesuai dengan karakteristik siswa. Carin \& Sund (1989, p.89) menyatakan:

Every action initiated by you to guide your students in their learning may be called your teaching methods. Some science educa- tors have grouped these two types of teacher/ student transactions into taxonomy of three large groups of common teaching. (1) listening-speaking: auditory learning, students learn by hearing, (2) reading-writing: visual learning, students learn by seeing, (3) watching-doing: kinesthetic learning, students learn by doing.

Penggunaan metode pembelajaran yang tepat, yang mampu mangakomodir gaya belajar siswa akan membantu siswa dalam memahami konsep. Siswa dikatakan sudah memahami suatu konsep apabila siswa tersebut sudah mampu mengkonstruksi makna pesan-pesan dari pengajaran seperti komunikasi lisan, tulisan dan grafik. Adapun Anderson \& Krathwohl (2001, pp.70-76) menyatakan bahwa pemahaman konsep siswa meliputi 7 aspek, yaitu (1) interpreting: siswa mampu mengubah informasi ke dalam bentuk representasi yang lain, misalnya kata menjadi gambar, gambar menjadi kata, kata menjadi bilangan, dan lain-lain, (2) exemplifying: siswa mampu memberikan contoh tentang konsep-konsep yang sedang dipelajari, (3) classifying: siswa mampu mengklasifikasikan konsep-konsep umum menjadi kategori yang lebih spesifik dan mampu mendeteksi hubungan antara kategori tersebut, (4) summarizing: siswa mampu mempresentasikan sebuah pernyataan atau informasi dengan bahasa sendiri dari materi/ konsep yang sudah dipelajari, (5) inferring: siswa mampu menemukan sebuah pola antara konsep dengan atribut/contohnya, (6) comparing: siswa mampu mengidentifikasi kemiripan dan perbedaan antara dua atau lebih konsep/ide/masalah, dan (7) explaining: siswa mampu membentuk dan menjelaskan bagaimana sebab akibat dari suatu konsep.

Dalam pembelajaran dengan metode mind mapping ketujuh aspek pemahaman konsep tersebut dapat diwujudkan ketika siswa mengalami hal-hal berikut. Interpreting: siswa mampu mengubah informasi ke dalam bentuk representasi yang lain dalam mind map yang dibuat, misalnya kata menjadi gambar, gambar menjadi kata, kata menjadi simbol, dan lain-lain. 
Terdapat beberapa siswa membuat simbolsimbol sesuai dengan imajinasi mereka, misalnya perubahan fisika dari padat menjadi cair disimbolkan dengan gambar es krim yang mencair, konsep perubahan kimia disimbolkan dengan gambar erlenmeyer. Exemplifying: siswa mampu memberikan contoh tentang sifat dan perubahan materi dalam kehidupan sehari-hari, misalnya perkaratan besi, kapur barus menyublim, dan lain-lain.

Classifying: siswa mampu mengklasifikasikan konsep-konsep umum tentang sifat materi menjadi kategori yang lebih spesifik dan mampu mendeteksi hubungan antara kategori tersebut. Summarizing: siswa mampu mempresentasikan sebuah pernyataan atau informasi dengan bahasa sendiri dari materi/ konsep yang sudah dipelajari. Inferring: siswa mampu menemukan sebuah pola antara konsep perubahan materi dengan contohnya yang diungkapkan baik melalui mind map atau saat menjawab pertanyaan guru. Comparing: siswa mampu mengidentifikasi kemiripan dan perbedaan antara dua atau lebih perubahan-perubahan materi. Hal ini nampak saat praktikum di laboratorium, siswa dapat mengidentifikasi konsep perubahan fisika dan kimia. Explaining: siswa mampu menjelaskan bagaimana sebab akibat dari suatu konsep melalui presentasi mind map di depan kelas.

Hasil penelitian ini menunjukkan bahwa tidak ada interaksi antara metode pembelajaran dan gaya belajar terhadap pemahaman konsep siswa. Tidak ada interaksi antara metode pembelajaran dan gaya belajar tersebut menunjukkan bahwa kedua variabel tersebut memiliki pengaruh sendiri-sendiri terhadap pemahaman konsep siswa. Hal ini dapat dijelaskan melalui kesimpulan pertama dan kedua penelitian ini bahwa metode pembelajaran mind mapping memberikan pengaruh positif terhadap pemahaman konsep siswa dan perbedaan gaya belajar tidak memberikan pengaruh yang signifikan terhadap pemahaman konsep siswa.

\section{Simpulan dan Saran}

Berdasarkan hasil uji hipotesis yang telah dilakukan, diperoleh simpulan sebagai berikut: (1) terdapat perbedaan pemahaman konsep pada siswa yang melaksanakan pembelajaran IPA menggunakan metode mind mapping dengan siswa yang menggunakan metode ceramah dan presentasi, (2) tidak terdapat perbedaan pemahaman konsep antara siswa dengan gaya belajar visual, auditori, dan kinestetik baik pada kelas eksperimen yang menggunakan metode mind mapping maupun pada kelas kontrol yang menggunakan metode ceramah dan presentasi, dan (3) tidak terdapat pengaruh metode pembelajaran dan gaya belajar terhadap pemahaman konsep siswa.

Berdasarkan kesimpulan dari penelitian ini, maka dapat diberikan beberapa saran sebagai berikut: (1) bagi guru IPA disarankan untuk menggunakan metode pembelajaran mind mapping, hal ini dikarenakan melalui metode mind mapping dapat dijadikan alternatif dalam meningkatkan pemahaman konsep siswa. Melalui metode mind mapping siswa dapat terlibat aktif dan dapat menimbulkan minat serta motivasi belajar yang baik, sehingga pemahaman siswa diharapkan dapat meningkat, (2) perlu dilakukan penelitian tentang metode pembelajaran dengan analisis terhadap karakteristik siswa yang lainnya (prior knowledge, kecerdasan, motivasi, gaya kognitif, dan lain-lain) yang diperkirakan besar pengaruhnya pada pemahaman konsep siswa, dan (3) bagi peneliti selanjutnya dapat melaksanakan penelitian pada pengembangan metode mind mapping dengan melihat karakteristik materinya (struktural, prosedural, konsep, fakta, dan lain-lain).

\section{Daftar Pustaka}

Anderson, (1980).Cognitive psychology and its implication.San Francisco: W.H. Freeman.

Anderson, L.W. \& Krathwohl, D.R. (2001). A taxonomy for learning teaching and assesing (A revision of bloom's taxo- 
nomy of educational objectives). New York: Longman.

Bruner, J.S. (1979). The relevance of education. New York: WW. Norton \& Company.

Budd, J.W. (2003). Mind maps as classroom exercises, industrial relations landgrant term professor. Diakses pada tanggal 6 Agustus 2012 dari, http://www. legacyirc.csom.umn.edu/faculty/jb udd/mindmaps/mindmaps.pdf.

Budiningsih, C.A. (2004). Karakteristik siswa, sebagai pijakan pembelajaran, Diktat kuliah. Yogyakarta: FIP Universitas Negeri Yogyakarta.

Budiningsih, C.A. (2005). Belajar dan pembelajaran. Jakarta: Rineka Cipta.

Buzan, T. (2012).Buku pintar mind map. Jakarta: PT Gramedia Pustaka Utama.

Carin, A.A. \& Sund, R.B. (1989).Teaching modern science. New York: Bell \& Howell Company.

de Porter, B. \& Hernacki, M. (2008). Quantum learning, membiasakan belajar nyaman dan menyenangkan. Bandung: Kaifa.

de Porter, B., Reardon, M., \& Nourie, S.S. (2008). Quantum teaching, mempraktikkan quantum learning di ruangruang kelas. Bandung: Kaifa.

Dryden, G. \& Vos, J. (1999).The learning revolution. Auckland: The Learning Web.

Gilakjani, AP. (2012). Visual, auditory, kinesthetic learning styles and their impacts on english language teaching. Journal of Studies in Education. ISSN 2162-6952.Vol. 2, No. 1.Diambil tanggal 20 Juni 2013 dari www. macrothink.org

Kerlinger, F.N. (2004). Foundation of behavioral research, $3^{\text {rd }}$ edition. (Terjemahan Landung Simatupang). Yogyakarta:
Gajah Mada University Press. (Buku asli diterbitkan tahun 1986).

Martin, R., Sexton, C., Franklin, T., \& Gerlovich, J. (2005).Teaching science for all children inquiry methods for constructing understanding. United States of America: Pearson Education, Inc.

Meier, D. (2000). The accelerated learning handbook. New York: The McGrawHill Companies.

Monks, F.J. \& Knoers, A.M.P. (2006). Psikologi perkembangan. Yogyakarta: UGM Perss.

Phillips, J.L. Jr. (1969). The origins of intellect piaget's theory. San Fransisco: W.H freeman Company

Putra, Y.P. (2008). Memori dan pembelajaran efektif, total mind learning (TML) series. Bandung: Yrama Widya.

Riding, R. (2002). School learning and cognitive style. London: David Fulton Publisher.

Seels, B.B \& Richey, R.C. (1994). Teknologi pembelajaran definisi dankawasannya. Jakarta: Unit Penerbitan Universitas Negeri Jakarta.

Sprenger, M. (2011).How to teach so students remember?. Jakarta: Penerbit Erlangga.

Swadarma, D. (2013). Penerapan mind mapping dalam kurikulum pembelajaran. Jakarta: Elex Media Komputindo.

Tuckman, B.W. (1972). conducting educational research, $5^{\text {th }}$ edition. San Diego: Harcourt Brace College Publisher.

Wilis, J. (2011). Research-based strategies to ignite student learning. (Terjemahan Akmal Hadrian). Yogayakarta: Mitra Media.

Windura, S. (2009).Mind map, langkah demi langkah. Jakarta: Elex Media Komputindo 